The Historical Journal, 58, 2 (2015), pp. 367-392 (C) Cambridge University Press 2015 . This is an Open Access article, distributed under the terms of the Creative Commons Attribution licence (http://creativecommons.org/licenses/by/3.o/), which permits unrestricted re-use, distribution, and reproduction in any medium, provided the original work is properly cited.

doi:10.1017/Soo $18246 \mathrm{X}_{14} 4000478$

\title{
POLICING PEDDLERS: THE PROSEGUTION OF ILLEGAL STREET TRADE IN EIGHTEENTH-CENTURY DUTCH TOWNS*
}

\author{
DANIELLE VAN DEN HEUVEL \\ School of History, University of Kent
}

\begin{abstract}
Street vending was a common feature in many towns in early modern Europe. However, peddlers and hawkers often operated outside the official framework, lacking permission from governments and guilds. The impact of their informal status has hitherto not featured very extensively in historical studies. This article assesses the impact of policing of street vendors by looking at familiar source materials in a new way. Rather than solely focusing on those people who were ultimately punished, this article investigates the full process of policing and prosecution of street traders in eighteenth-century Dutch towns. It exposes that apart from those receiving a formal punishment, many more traders could suffer from policing activities, and that particular groups of street vendors were more vulnerable than others due to the specific dynamics of local power relations. As such, this article provides new insights into policing and social control, while also offering wider lessons for our understanding of the relationship between the formal and informal economy in pre-industrial Europe.
\end{abstract}

School of History, Rutherford College, University of Kent, Canterbury, CT2 $7^{N X}$ d.vandenheuvel@ kent.ac.uk

* The research for this article has been generously funded by the British Academy. It has greatly benefited from a rich paper by Thera Wijsenbeek-Olthuis who unfortunately passed away before it could be published. I would like to express my gratitude for her generosity in sharing her results with me. Thanks furthermore go to panels and audiences at the 2009 WEHC, CHORD, and the 2011 SSHA conferences, as well as the audience at the Early Modern European History Seminar of the University of Cambridge. I would also like to thank Kenneth Fincham, Laurence Fontaine, Jelle van Lottum, Sheilagh Ogilvie, Jeroen Salman, the History Students and Fellows of Girton College Cambridge, the anonymous reviewers, and the editor of this journal, for their comments and suggestions for further improvements of the article. 
Whether it concerns past or present societies, the informal economy has always been vital for the survival of so-called 'marginal' groups. ${ }^{1}$ Eighteenth-century Europe was no exception to this. Depending on the setting, the people who lived on the margins of society varied, but they generally included the poor, as well as independent women, religious minorities, and immigrants. These groups often made a living in various casual forms of work and related activities aptly labelled 'the economy of makeshift' by Olwen Hufton. ${ }^{2}$ In pre-industrial Europe, this could include menial unskilled jobs and begging, but a substantial part of the makeshift economy was ambulant trading. The importance of the latter is difficult to overstate: not only did street selling provide opportunities to the poor to earn a living, the services of peddlers and hawkers were also essential for large numbers of people of modest means depending on cheap merchandise. 3 Nevertheless, as is characteristic of all activities in the informal economy, street vending was generally restricted through legislation and policing activities by local authorities and guilds. One would expect such restrictions to have impact on the activities, earning potential, and agency of the people involved. Yet, contrary to studies by development economists, such potential consequences of legislation on ambulatory sales activities do not feature very

${ }^{1}$ Since it was first coined in the 1970 s, scholars have had difficulties precisely defining the concept of the 'informal economy' (previously the 'informal sector'). Most authors now agree that the informal economy, or shadow economy, exists of (generally) small-scale economic activities which (at least partly) escape regulation, taxation, and observation. In modern developing economies, it typically includes activities such as domestic work, home-based work, waste picking, and street vending. Informal activities can be illegal in nature, for instance when unregulated traders sell their wares in the black market, but are not necessarily illicit and scholars increasingly stress the interconnectedness of formal and informal worlds through goods and people. For a discussion of how the concept evolved see: http://wiego.org/informaleconomy/history-debates. For historical examples of the informal economy, see for example Claire Holleran, Shopping in Ancient Rome: the retail trade in the late Republic and the Principate (Oxford, 2012), pp. 216-23; Maryanne Kowaleski, 'Women's work in a market town: Exeter in the late fourteenth century', in B. A. Hanawalt, ed., Women and work in preindustrial Europe (Bloomington, IN, 1986), p. 15 ; Sheilagh Ogilvie, Bitter living: women, markets, and social capital in early modern Germany (Oxford, 2003), p. 169; Laurence Fontaine, 'Märkte als Chance für die Armen in der Frühen Neuzeit', Zeitschrift für Agrargeschichte und Agrarsoziologie, 59 (2011), pp. 37-53; Henry Mayhew, London labour and the London poor (London, 1851); Hernando De Soto, The other path: the invisible revolution in the third world (New York, 1989), pp. $212-13$.

${ }^{2}$ Olwen Hufton, The poor of eighteenth-century France (Oxford, 1974) p. 15 .

3 M. Wiesner Wood, 'Paltry peddlers or essential merchants? Women in the distributive trades in early modern Nuremberg', Sixteenth Century Journal, 12 (1981), pp. 3-14; Laurence Fontaine, History of pedlars in Europe (Cambridge, 1996); Hannelore Oberpenning, Migration und Fernhandel im Tödden-System: Wanderhändler aus dem nördlichen Münsterland in mittleren und nördlichen Europa (Osnabrück, 1996); J. Salman, 'Peddling in the past: Dutch itinerant bookselling in a European perspective', Publishing History, 53 (2003), pp. 2-26; G. Brunelle, 'Policing the monopolizing women of early modern Nantes', Journal of Women's History, 19 (2007), pp. 10-35; Sheilagh Ogilvie, Janine Maegraith, and Markus Küpker, 'Krämer und ihre Waren im ländlichen Württemberg zwischen 1600 und 1740', Zeitschrift für Agrargeschichte und Agrarsoziologie, 59 (2011), pp. 54-75. 
prominently in historical studies. 4 Indeed, when it comes to the enforcement of regulation directed at street vendors, most studies on ambulant trading in early modern Europe include an intriguing paradox.

The regulation of the activities of street sellers by regulatory bodies such as guilds and municipal governments is commonly acknowledged in studies that deal with pre-industrial street vending. 5 Most scholars also agree on the fact that, as a result of restrictive regulations, many peddlers and hawkers operated on the fringes of legality, and regularly, if not permanently, crossed this line and entered the black market. ${ }^{6}$ In addition, almost all studies on ambulant trading in early modern Europe report of surveillance activities and the imposing of punishments in order to stop illegal sales activities by itinerants.7 Interestingly, however, whilst the informal status of street vendors and their activities, as well as the almost automatic reactions of authorities to suppress them, are standard features in works on pre-industrial retail practices, the same studies generally question such measures as having had an important effect on the proliferation of street vending. Instead, as is common in discussions on the pre-industrial economy more generally, these studies stress the complementary relationships of formal and informal economies. ${ }^{8}$ Scholars describe what they call 'flexible attitudes' towards people infringing on guild monopolies, and emphasize the great levels of toleration of guilds and

4 For example De Soto, Other path; Narumol Nirathon, Fighting poverty from the street: a survey of street vendors in Bangkok (ILO Informal Economy, Poverty, and Employment Series, 1, Geneva, 2006).

5 Fernand Braudel, The wheels of commerce: civilization and capitalism 15 th -1 8th century (3 vols., London, 2002; original edition 1982), II, pp. 75-80; Margaret Spufford, The great reclothing of rural England: petty chapmen and their wares in the seventeenth century (London, 1984), pp. 6-9; Fontaine, Pedlars, pp. 22-8; Oberpenning, Migration, pp. 290, 294; J. E. Shaw, The justice of Venice: authorities and liberties in the urban economy (Oxford, 20o6); Brunelle, 'Policing'; J. C. Streng, Vrijheid, gelijkheid, broederschap en gezelligheid: het Zwolse Sint Nicolaasgilde (Hilversum, 2001), ch. 3; Danielle van den Heuvel, Women and entrepreneurship: female traders in the Northern Netherlands, c. I580-I $8_{15}$ (Amsterdam, 2007), pp. 91-3, 104, 108; Jeroen Salman, "Vreemde lopers en kramers": de ambulante boekhandel in de Republiek', Jaarboek voor Nederlandse boekgeschiedenis, 8 (2001), pp. 73-98; M. Bot, 'Het Haarlemse Comansgilde: de strijd tegen de ventjagerij in de zeventiende en achttiende eeuw en de uiteindelijke afschaffing van dit gilde' (MA thesis, Amsterdam, 1996), pp. 26-31.

6 Fontaine, Pedlars, pp. 32-3; Oberpenning, Migration, p. 293; Brunelle, 'Policing'.

7 Fontaine, Pedlars, p. 170 ; Salman, 'Peddling'; Evelyn Welch, Shopping in the Renaissance: consumer cultures in Italy, I400-I 600 (New Haven, CT, 2005), pp. 72-3; H.-C. Mui and L. Mui, Shops and shopkeeping in eighteenth-century England (London, 1989), p. 98; Shaw, Justice, pp. 70-4; Brunelle, 'Policing'.

8 Cf. Maarten Prak, 'Moral order in the world of work: social control and the guilds in Europe', in Herman Roodenburg and Pieter Spierenburg, eds., Social control in Europe: I5ooI 800 ( 2 vols., Columbus, OH, 2004), I, pp. 191-2; P. R. Hoffmann, 'In defence of corporate liberties: early modern guilds and the problem of illicit artisan work', Urban History, 34 (2007), pp. 76-88; Th. Buchner and P. R. Hoffman-Rehnitz, 'Introduction: irregular economic practices as a topic of modern (urban) history - problems and possibilities', in Th. Buchner and P. R. Hoffman-Rehnitz, ed., Shadow economies and irregular work in urban Europe: sixteenth to twentieth centuries (Vienna, 2011), pp. 19-35. 
governments in respect of irregular work. 9 They furthermore point out that many guild members also operated in the black market, or used black markets to their own advantage, for instance through buying raw materials from unlicensed traders, or by hiring illicit workers. ${ }^{10}$ In addition, it is argued that people operating in the grey zones of the market used the legal system to their own benefit, and were even able to exploit systematically the shortcomings of the surveillance system. ${ }^{11}$ As such, the interwovenness of legal and illegal economic worlds, the agency of shadow workers, and the (deliberate) failure of governing bodies to clamp down on black-market activities are proposed as explanations of why we observe widespread illegal economic activities despite restrictive regulation and observations of repressive policing.

While it is very important to expose how formal and informal worlds of work are connected, and to establish the effect this had on power relations in the early modern society, such an approach obscures several issues that are important for our understanding of the workings of especially the lower segments of the pre-industrial economy. First, it blurs the difference between the legal and illegal economy. The fact that legal and illegal economies were connected through people and goods does not make them equal. To name just one important difference: it is clear that operating in the black market could have serious consequences in the form of penalties; these were not imposed when operating in the official economy. ${ }^{12}$ Furthermore, it is also clear that while some people may have been able to move relatively freely between formal and informal economies, and as such exploit the advantages of both systems, others could not. Indeed, several groups of people who were excluded from substantial segments of the official economy through for instance guild regulation, such as women, immigrants, and Jews, had, depending on the context, no or much more limited opportunities of crossing the line from informal to formal work. ${ }^{13}$ It is very likely therefore that for these groups, operating in the black market had different consequences than for those who voluntarily, and often only temporarily, crossed this line. Existing studies on informality in early modern Europe, however, provide little insight into the experiences of different types of black-market workers.

9 Shaw, Justice, p. 104; Brunelle, 'Policing', pp. 20-7; J. R. Farr, Artisans in Europe, I330-I9I4 (Cambridge, 200o), p. 89; Buchner and Hoffman-Rehnitz, 'Introduction', p. 24.

${ }^{10}$ A. Montenach, 'Formal and informal economy in an urban context', in Buchner and Hoffman-Rehnitz, eds., Shadow economies, p. 98; S. Kaplan, 'Les corporations, les faux ouvriérs et le faubourg Saint Antoine au XVIII siècle', Annales, 43 (1988), pp. 353-78; Bert De Munck, 'One counter and your own account: redefining illicit labour in early modern Antwerp', Urban History, 37 (2010), pp. 26-44; see also Pieter Spierenburg, 'Social control and history: an introduction', in Roodenburg and Spierenburg, Social control, p. 17.

11 Montenach, 'Formal', p. 104.

12 Another example is the fact that those who operate in the formal economy generally have a say in how the economy is regulated, and informal workers tend to lack such influence.

13 See also Ogilvie, Bitter living, pp. 3o6, 308. 
Secondly, the recent portrayals of the informal economy in early modern Europe fail to illuminate the actual restrictions that working in the shadows of the regulated economy imposed on people. The emphasis on how people were able to negate and to manipulate the system suggests that the restrictions that were imposed on those working in the black market did not really matter; people simply got round them. In this context, much weight is placed on the agency of the people who operated in the informal economy, and how their agency would have allowed them to exploit the system to their own advantages. ${ }^{14}$ Yet, while in many cases informal workers may have had this opportunity, the observation that some people were able to manipulate some segments of the system does not automatically imply that the system as such did not restrict their economic activities, nor that all informal traders were able to work around restrictions. James Shaw, for instance, showed that in Venice only wealthier traders could afford to bribe officials in order to avoid prosecution. ${ }^{15}$ Moreover, as we will read below, even if illegal itinerants were ultimately not imposed a penalty, the surveillance and the prosecution in itself, even in the end unsuccessful, could have large consequences for street traders as well as their customers.

Thirdly, in a number of studies which stress the co-existence and overlap of formal and informal worlds of work the overall impact of policing is questioned. ${ }^{16}$ In these studies, it is generally argued that policing activities by local governments and guilds were not effective as evidence shows that blackmarket activities were abundant and that those arrested were able to use their negotiating powers to avoid actual penalties. ${ }^{17}$ However, one can seriously question how one would measure the effectiveness of policing measures. Does the latter hold true if all black-market trade disappeared? If not, what share of shadow activities should need to disappear in order to be able to call policing thereof 'effective'? This is probably as difficult a question to answer as it is to establish the actual number of informal sales activities, and one may therefore wonder whether assessing policing activities in terms of its effectiveness is ultimately very helpful for our understanding of the phenomenon. More importantly, perhaps, the assumption that the surveillance of illegal street trade was ineffective purely based on observations of the number of people who were arrested, or who were observed selling wares even in restrictive regulatory regimes, also dismisses the potentially wide-ranging effects of policing on the people involved, and the wider economy. ${ }^{18}$

${ }^{14}$ This idea of bending the rules of the game fits into wider discussions of the impact of social control in pre-industrial Europe. Spierenburg, 'Control', p. 17.

15 Shaw, Justice, p. 92.

${ }^{16}$ For instance Prak, 'Moral order', p. 185.

${ }_{17}$ Peter Stabel, 'From the market to the shop: retail and urban space in late medieval Bruges', in Bruno Blondé, Peter Stabel, Jon Stobart, and Ilja Van Damme, eds., Buyers and sellers: retail circuits and practices in medieval and early modern Europe (SEUH 9, Turnhout, 2006), p. 104; Montenach, 'Formal'; Brunelle, 'Policing'.

${ }^{18}$ De Soto, Other path, pp. $15^{2-8 .}$ 
In sum, the current emphasis on flexibility, negotiation, and the overlap between formal and informal economies fails to illuminate what precise effects regulatory regimes and the resulting surveillance had on the different groups of people operating as informal street vendors. ${ }^{19}$ This article aims to enhance our understanding of the workings of the pre-industrial informal economy and the implications of being part of it by shedding light on the mechanisms and consequences of retail regulations, surveillance, and punishment. It does so by examining in detail the policing of ambulant traders in the most dynamic economy of early modern Europe: the Dutch Republic. As is the case for social scientists studying the informal economy in contemporary contexts, also for historians it is difficult to obtain quantitative information on the people involved and the type of work they are in. However, by following methods developed by social scientists (and, in fact, other historians studying the informal economy), which allow for successfully studying informality through combining the available quantitative evidence with qualitative materials, it will be possible to uncover the mechanisms that create an informal economy, and map out what consequences such mechanisms had for the different people involved. ${ }^{20}$ This article does so by looking in a new way at familiar source materials such as petitions, court cases, and guild records including printed sales licences, lists of fines, and guild ordinances. Rather than solely assessing the 'net result' of prosecution, i.e. those who received a formal penalty, this article takes a broader view of the impact of policing by incorporating activities that occurred before a formal punishment, derived principally from petitions and court cases. As a result, it reveals that regulatory regimes, even those designed to be fair and that can be regarded as relatively liberal, could greatly impact on the economic lives of people on the margins of early modern society.

\section{I}

In the Dutch Republic, the governance of the retail sector was a shared responsibility of local governments and guilds. The municipal authorities generally were responsible for setting market times and specifying market spaces, but they delegated much of the day-to-day governance of markets to the retail guilds. ${ }^{21}$ In addition, retail guilds carried the prime responsibility of governing

\footnotetext{
${ }^{19}$ See also Prak and Epstein's call for a move beyond the flexibility discourse in the debates about craft guilds. S. R. Epstein and M. Prak, 'Introduction: guilds, innovation and the European economy, 1400-1800', in S. R. Epstein and M. Prak, eds., Guilds, innovation, and the European economy, I $400-1800$ (Cambridge, 2008), p. 3.

${ }^{20}$ For example Zoe Horn, No cushion to fall back on: the global economic crisis and informal workers

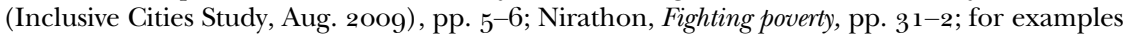
of recent historical studies of informal workers, see the contributions in Buchner and HoffmanRehnitz, Shadow economies.

${ }^{21}$ Van den Heuvel, Women, pp. 91-9, 147-53.
} 
shop-based retailing. In most Dutch towns, to be able to engage in retailing on a permanent basis one needed to be a member of one of the local retail guilds. ${ }^{22}$ Retail guilds claimed the right of selling goods in small quantities and their ordinances usually stated that anyone who used a scale and weights when selling was obliged to acquire its membership. ${ }^{23}$ Very often, towns had multiple guilds that governed the retail trades, with on the one hand market-based guilds such as those of fishmongers and fruit vendors, and on the other hand the shopbased guilds such as the general shopkeepers' guilds (called kramersgilden) and specialized shop-based guilds such as those of textile vendors.

Membership numbers of retail guilds were generally much higher than those of craft guilds. In Utrecht in 165 o, the retailers' guild was the fifth largest guild;

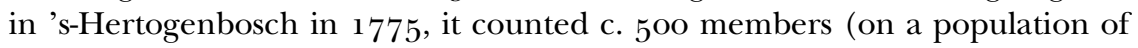
14,0oo), and in the eighteenth century the Zwolle retail guild was the largest in the city. ${ }^{24}$ Several historians have attributed their large memberships to retail guilds' relatively low entry barriers as compared to craft guilds which generally demanded long apprenticeships and much higher entry fees. ${ }^{25}$ Nevertheless, in the context of this article, it is important to state that retail guilds still only accepted citizens as members, and generally favoured men over women, guild members' offspring over others, and Protestants over people from other religious denominations (especially Jews). ${ }^{26}$ Equally

${ }^{22}$ In the Dutch Republic, guilds were mostly an urban feature as very few rural guilds existed. Moreover, contrary to for instance London guilds, Dutch guilds had very limited powers in rural areas, only able to exert influence on the countryside directly surrounding the city or town. Cf. Bert De Munck, Jan Lucassen, and Piet Lourens, 'The establishment and distribution of craft guilds in the Low Countries, 1000-1800', in Maarten Prak, Catharina Lis, Jan Lucassen, and Hugo Soly, eds., Craft guilds in the early modern Low Countries: work, power and representation (Aldershot, 2006), pp. 32-73.

23 Streng, Vrijheid, 46, C. D. Jongman, 'De ontwikkeling van het kruideniersbedrijf na het einde van de $16^{\text {de }}$ eeuw', in F. L. Muiswinkel, ed., Het kruideniersbedrijf: een studie over het kruideniersbedrijf in Nederland Amsterdam, 1951), p. 116 ; Van den Heuvel, Women, p. 149.

24 Nico Slokker, Ruggengraat van de stad: de betekenis van gilden in Utrecht, ${ }_{152}{ }_{2}{ }_{I} 8_{I} 8$ (Amsterdam, 2010), p. 50, Maarten Prak, Republikeinse veelheid, democratisch enkelvoud: sociale verandering in het Revolutietijdvak 's-Hertogenbosch I770-I82o (Nijmegen, 1999), p. 91, and Streng, Vrijheid, p. $5^{2}$.

${ }_{25}$ Prak, Republikeinse veelheid, p. $5^{1}$; Erwin Steegen, Kleinhandel en stedelijke ontwikkeling: het kramersambacht te Maastricht in de vroegmoderne tijd (Hilversum, 20o6), pp. 137, 195-6; L. H. Remmerswaal, Een duurzame alliantie: gilden en regenten in Zeeland, I6oo- I80o (Middelburg, 2009), pp. 42, 87, 97; Streng, Vrijheid, p. 49; P. Stabel, 'Social mobility and apprenticeship in late medieval Flanders', in B. De Munck, S. Kaplan, and H. Soly, eds., Learning on the shop floor: historical perspectives on apprenticeship (International Studies in Social History, 12, Oxford, 2007), p. 161; Salman, 'Peddling', p. 9 .

${ }^{26}$ Van den Heuvel, Women, pp. 152, 166; Danielle van den Heuvel, 'Partners in marriage and business? Guilds and the family economy in urban food markets in the Dutch Republic', Continuity and Change, 23 (2008), pp. 221-6; Bot, 'Comansgilde', p. 15; Streng, Vrijheid, pp. 112, 127; Steegen, Kleinhandel, pp. 199, 205; Remmerswaal, Alliantie, pp. 120-3. Craftsmen were allowed to sell the goods they had produced themselves in retail, but if they wanted to sell goods produced by others as well, they were generally forced to obtain the membership of the local retail guild. 
important is that despite the fact their entry fees were a fraction of what some craft guilds required, the total financial costs for obtaining guild membership still hampered entry for those of lesser means, including independent women and poor immigrants. Finally, the abolishment of retail guilds at the end of the eighteenth century coincided with a significant upsurge in retail density, allowing those who were previously unable to set up shops, including many immigrant peddlers, to enter into the previously guild-controlled sedentary retail sector. ${ }^{27}$

People who were not members of retail guilds were limited in the opportunities to sell their wares. Local variation in market and retailing regulation existed throughout the country, but, in general, non-guild members, both town residents (citizens and non-citizens) and strangers, could only engage in retailing during the annual fairs and weekly markets. ${ }^{28}$ Even during these fairs and markets, guild members often had priority over the non-guild members, for instance when stalls were assigned to vendors and in the number of hours they were allowed to sell. This had very important implications, as many inhabitants of early modern towns did not have citizenship rights, and were hence excluded from guild membership.

In addition, there were strict regulations against door-to-door retailing in most Dutch towns. In early seventeenth-century The Hague this practice was only permitted when the value of the commodities was less than six shillings, but after ${ }_{1676}$ door-to-door selling was completely forbidden. ${ }^{29}$ In Haarlem, the ban on door-to-door selling concerned both guild members and nonguild members alike. $3^{\circ}$ Only in certain trades, such as the fish trade, were non-local traders allowed to hawk their wares outside the market places, but they were only permitted to do so during set times. In The Hague, fish hawkers could only sell between noon and $2 \mathrm{pm}$ and after $7 \mathrm{pm}$, and in Leiden, the wives of fishermen from neighbouring coastal towns were only allowed to hawk their catch in the mornings, and were furthermore limited

\footnotetext{
${ }_{27}$ Oberpenning, Migration, pp. 292-4; Marlou Schrover, Een kolonie van Duitsers: groepsvorming onder Duitse immigranten in Utrecht in de negentiende eeuw (Amsterdam, 2002), pp. 234, 263-4; J. van Lottum, 'Immigranten in Nederland in de eerste helft van de 19e eeuw: een onderzoek op basis van de Utrechtse volkstellingen van 1829 en 1839', IISG Research Papers, 43 (Amsterdam, 2004), pp. 44-5, Danielle van den Heuvel and Sheilagh Ogilvie, 'Retail development in the consumer revolution: the Netherlands, c. 1670 - c. 1815 ', Explorations in Economic History, 5o (2013), pp. 69-87; Danielle van den Heuvel, 'Guilds, gender policies and economic opportunities for women in early modern Dutch towns', in Deborah Simonton and Anne Montenach, eds., Female agency in the eighteenth-century urban economy: gender in European towns, ${ }_{1640-1830}$ (London, 2013), pp. 116-33. See Braudel, Wheels, p. 8o, for similar patterns in France.

${ }^{28}$ See Streng, Vrijheid, pp. 179-9o; Bot, 'Comansgilde', pp. 20-1; Jongman, 'Kruideniersbedrijf', pp. 116-23; Gelders Archief (GA), Gasthuizen en gilden Arnhem (GGA), no. 1442 .

${ }^{29}$ Gemeentearchief Den Haag (GDH), Archief ambachtsgilden en bussen (AAB), no. 124; Jongman, 'Kruideniersbedrijf', p. 59 .

30 Bot, 'Comansgilde', p. 23.
} 
in the quantity of fish they could sell. In Leiden, fish hawkers were also obliged to obtain a permit specifically designed for the selling of fish from door to door. ${ }^{31}$

Outside the periodical markets, and excluding specific trades such as the fish trade, traders who were not guild members could sell only when they had obtained a sales licence. ${ }^{2}$ These licences, consentbriefjes, were generally bought from the local shopkeepers' guilds, which used the revenues generated from selling licences to cover standard guild expenses.33 In the town of Zwolle, the price of a licence was $0 \cdot 3$ guilders, equivalent to half a working day of an unskilled labourer, and twice the amount guild members had to pay as annual dues. ${ }^{34}$ The conditions to these licences differed throughout the country. Whereas in Zwolle they only allowed for selling in bulk to the members of the local shopkeepers' guild, in most other towns the licence allowed for selling both in retail and in bulk.35 In Haarlem, a sales licence was even required for non-guild members to sell in retail to consumers in the weekly markets. $3^{6}$ Furthermore, the time that the sales licences were valid for also varied, albeit that it was always a limited period. For example, in the city of Haarlem in 1664 the licence was valid for four days; in early seventeenthcentury The Hague and mid-eighteenth-century Zwolle for three days. 37 The limited time span of these licences meant that they had to be bought time and again, increasing both the actual costs of purchasing a licence for a regular trader, as well as opportunity costs involved in the time and effort it took to purchase and register the licence with the guild. If we take the example of Zwolle, buying one licence per week would amount to 15.60 guilders per annum, whereas being able to sell throughout the year would amount to $36.5^{\circ}$ guilders annually. $3^{8}$ This shows that although street vending

31 Jannie Stegeman, 'Scheveningse visverkoopsters ca. 16oo-1900', Holland, 21 (1991) p. 46; Regionaal Archief Leiden, Archief van de gilden, beurzen en rederijkerskamers, no. 1215 .

$3^{2}$ GA, GGA, nos. 1442 and 1448 . In his 2007 article on pamphlet sellers Harms claims that in most cases street vendors did not require a sales licence in the Dutch Republic; this, however, appears not to be true for street vending in many urban cores. R. J. Harms, 'Handel in letteren: de ambulante handel in actueel drukwerk in zeventiende-eeuws Amsterdam', De zeventiende eeuw, 23 (2007), p. 217.

33 Streng, Vrijheid, pp. 84-92; Bot, 'Comansgilde', pp. 27-8; Oberpenning, Migration, p. 292.

34 Streng, Vrijheid, p. 64 .

35 Ibid.

$3^{6}$ Bot, 'Comansgilde', p. 23 .

37 Streng, Vrijheid, p. 35; Bot, 'Comansgilde', p. 27; Jongman, 'Kruideniersbedrijf', pp. 59-6o.

$3^{8}$ This was slightly more than the maximum cost of a guild membership (a little over thirty guilders), but this did not include the compulsory purchase of community citizenship for migrants wanting to become guild members, which stood at forty-one guilders in 1767 . Streng, Vrijheid, p. 50; P. Lourens and J. Lucassen, "Zunftlandschaften" in den Niederlanden und im benachbarten Deutschland', in W. Reininghaus, ed., Zunftlandschaften in Deutschland und den Niederlanden im Vergleich (Münster, 20oo) p. 16. 
had a designated place within the Dutch urban retail system, opportunities for salespeople who were not members of local retail guilds were limited. The question therefore arises what happened when street vendors did not keep to the rules. How did the retail establishment and guild and government authorities respond to illegal street vendors?

\section{I}

The local retail guild was the principal actor in policing the various hawkers and peddlers in urban areas of the Dutch Republic. The municipal authorities were generally only proactive in policing illegal traders when people were suspected of selling stolen wares, or when street vendors were disturbing the public order. The infringement of guild monopolies by street traders was something they mostly left the guilds themselves to deal with.39 This was very different from the situation in several other countries in early modern Europe. In seventeenth-century England, both guild officials and civic authorities charged illegal traders, a situation that can also be found in early modern Venice. $4^{\circ}$ In Vienna, municipal authorities, and occasionally also military and feudal officials, were in charge of prosecuting illegal traders, and in Lyon, a governing body called the consulate, made up of people with a background as craftsmen and magistrates, was the principal actor in setting retail regulation and guaranteeing its enforcement. $4^{1}$ Occasionally in Dutch cities municipal officials were called in for assistance by the local guild. This could occur either on a temporary basis, for instance by assisting guild officers in patrolling streets and markets, and in searching shops and inns, or on a more permanent basis. The latter happened in the town of Arnhem from 1736 onwards, when it was decided that in return for part of the money that was collected, the town's mayors were to assist the guild in collecting the fines, and in The Hague after $175^{6}$ when municipal officials were required to assist with the collection of fines that exceeded the amount of three guilders. $4^{2}$

Within most shopkeepers' guilds it was the guild clerk's task to identify illegal traders, to check whether they had obtained the appropriate permission, and to determine whether they obeyed the rules set out by the guild and the municipal authorities.43 Members of the shopkeepers' guilds, both ordinary members as well as members of the guilds' governing body, were also often involved in

39 Th. Wijsenbeek-Olthuis, 'Gestolen goed. Diefstal van textiel in Den Haag 16oo-180o', Textielhistorische Bijdragen, 47 (2007), 58; Salman, 'Kramers', pp. 80-4; Harms, 'Handel'.

$4^{\circ}$ Ronald M. Berger, The most necessary luxuries: the mercers' company of Coventry, 1550-1680 (University Park, PA, 1993), p. 173; Shaw, Justice, p. 87.

$4^{1}$ G. Stöger, 'Disorderly practices in the early modern urban second-hand trade (sixteenth to early nineteenth centuries)', in Buchner and Hoffman-Rehnitz, eds., Shadow economies, pp. 141-64, 152-3; Montenach, 'Formal', p. 92.

$4^{2}$ GA, GGA, no. 1442; Jongman, 'Kruideniersbedrijf', p. 122. See also Shaw, Justice, p. 87.

43 GA, GGA, no. 1448; Streng, Vrijheid, pp. 190-2; Remmerswaal, Alliantie, pp. 116-17; Bot, 'Comansgilde', p. 27. 
policing illegal traders. 44 In the Zeeland town of Zierikzee, guild members were obliged to report any illegal sales activities they encountered to the guild officials. 45 In The Hague in the 1760 os the involvement of guild members in policing went even further, as it was not so much the guild clerk but rather the guild wardens and ordinary guild members who were the principal actors in the search for illicit trade activities. The guild's account books for this town show that in this period the warden and a few ordinary members did most of the apprehensions of illegal traders. $4^{6}$ Some shopkeepers' guilds even went as far as actively encouraging the involvement of members of the public in policing informal traders, for instance by asking for their help in tracing illegal traders, in the actual arrests, and in the demolition of the property (carts and stalls) of people operating illegally. 47 In addition, it was not uncommon for guilds to turn to soldiers for assistance in apprehending illegal traders. $4^{8}$ In 1708 , for instance, the soldier Willem Jansen arrested the foreign salesmen Roelof van Dordth, who operated from the house of an Arnhem citizen, due to the appropriate officials being taken up by other tasks. 49

Anyone involved in the successful arrest of illegal traders was awarded a premium, which was very substantial..$^{\circ}$ In the 1770 os in Zwolle, for instance, to boost the enforcement of guild control, the guild clerk was awarded a premium comparable to 2.5 times the daily wage of an unskilled labourer for each illegal Jewish trader caught, and a Zwolle soldier once received a sum comparable to one day's wage of an unskilled labourer after he had chased and caught a Franse kramer (French mercer) far beyond the city gates. $5^{1}$ On the other hand, resignation loomed for the guild clerk when he was not active enough in uncovering fraudulent traders. $5^{2}$ The height of the premiums offered and the explicit threat of resignation suggests that it was necessary for the guilds' governments to offer substantial rewards in return for apprehensions, as well as severe penalties for when the task of policing was not taken seriously. This implies that whilst for guild authorities the nuisance of unlicensed traders was substantially severe, this was not the case for (all of) their members, and the general public. We will return to this issue later.

44 Bot, 'Comansgilde', pp. 27-8.

45 Remmerswaal, Alliantie, p. 116.

$4^{6} \mathrm{GDH}, \mathrm{AAB}$, no. 135 .

47 GA, GGA, no. 1405; GDH, AAB, no. 135; Streng, Vrijheid, pp. 74, 94; A. Vos, Burgers, broeders en bazen: het maatschappelijk middenveld in 's-Hertogenbosch in de zeventiende en achttiende eeuw (Hilversum, 2007), p. 61; Schrover, Kolonie, p. 234. See also Welch, Shopping, p. 93.

$4^{8}$ Streng, Vrijheid, p. 94, Vos, Burgers, p. 61.

49 GA, GGA, no. 1405 .

$5^{\circ}$ In contrast, payments for the guild clerk in Venice were very low. Shaw, Justice, p. 7 o.

$5^{1}$ Streng, Vrijheid, p. 94. The daily wage of an unskilled labourer in Zwolle in the second half of the eighteenth century varied between 12.88 stuivers and 11.88 stuivers. Jan de Vries and Ad van der Woude, The first modern economy: success, failure, and perseverance of the Dutch economy, 1550-1815 (Cambridge, 1997) pp. 612-13.

$5^{2}$ Streng, Vrijheid, p. 94 . 
The policing of black-market vendors by shopkeepers' guilds mostly occurred in urban streets and squares. As in the Dutch Republic, the guilds' powers were largely confined to the city or town they belonged to; most of their activities against illegal retailing took place within the city limits, although occasionally, as we have seen in the example above, suspects were pursued into the surrounding countryside. 53 Guild clerks were ordered to patrol the streets on a regular, sometimes daily, basis, in search for illegal sales activities.54 We find that in addition to patrolling the streets, they visited coffeehouses and inns. These were places where non-local traders tended to operate as it was legitimate to sell in inns and coffeehouses during annual fairs and markets. 55 The policing of illegal traders even continued after nightfall, as evidence from Arnhem shows that the guild clerk of the local shopkeepers' guild also went out on patrol in the evenings. $5^{6}$

In most towns, the searches for illegal peddlers went hand-in-hand with searches for other types of black-market or fraudulent retail activities, such as holding a shop without a guild membership or using faulty weights. 57 From ordinances of various shopkeepers' guilds, we learn that guild clerks were to target not only peddlers and hawkers, but also bargemen who had just arrived in the town. Furthermore, evidence from petitions indicates that guild representatives targeted local shopkeepers in a similar manner to itinerant traders, with unannounced visits to their shops to see if the proprietors had indeed acquired the obligatory guild membership. $5^{8}$ The guild representatives used a range of tactics to take informal traders by surprise. Guild clerks hid behind trees to spy on people; other times they acted as bait, waiting for black-market traders to offer them goods, and they used informers, paying local people who were not even affiliated to the guild for keeping an eye out for black-market activities. 59

Despite being set by local guilds, the official procedures of reporting illegal sales activities and punishing the offenders were uniform across the Netherlands. ${ }^{60}$ When identified as engaging in illegal selling by the guild clerk or one of his accomplices, vendors were generally brought before a representative of the guild's governing body. From the perspective of the guild, the ideal scenario was to convince the arrested sellers either to become a guild member (when one was resident in the town and willing and able to become a citizen and to purchase a guild membership), or to buy the appropriate sales permit (in all other

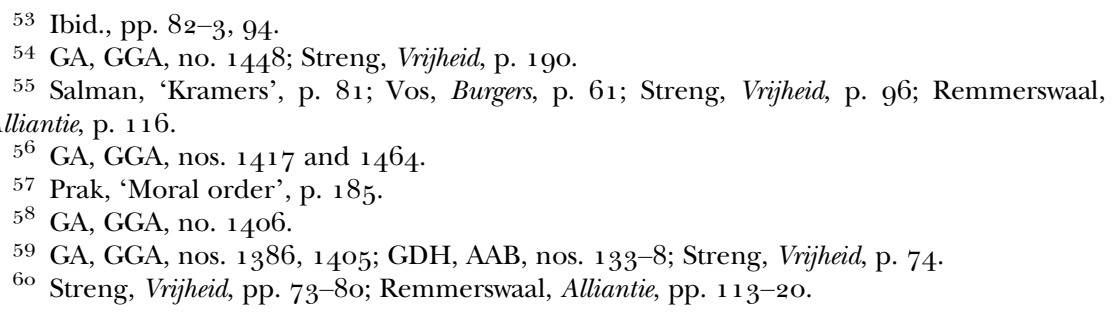


cases). When traders did not voluntarily follow the guild representatives to the guild officials, the representative of the guild (be it a clerk, warden, or ordinary member) was allowed to confiscate the goods the vendor was selling. On acquiring the appropriate licence, the goods were returned, but when the trader was unwilling to buy guild membership or a permit, he was fined and the confiscated goods were sold. Although generally the height of fines was set in the guild ordinances, substantial variation existed in the amount to be paid for the different transgressions of the guild monopoly, and hence in what was ultimately paid to the guild by the fined traders. Fines paid in the western city of The Hague ranged between a low of 1 guilder and a high of 30.8 guilders, the latter an equivalent of one month's wages for an unskilled labourer. In the eastern town of Arnhem, the fines varied even more and ranged between 0.3 guilders and 39.5 guilders, the maximum equalling the wage paid for two months unskilled labour, and, as we saw earlier, exceeding buying sales licences for a year. ${ }^{61} \mathrm{We}$ will go into the consequences of such fines below. The revenues from the arrests of illegal street vendors and the sale of their goods were used to pay the people who executed or facilitated the arrests, and the remainder was shared with local charitable institutions. ${ }^{62}$

The official guidelines set out by the various shopkeepers' guilds seemed designed to guarantee a fair treatment of people suspected of selling without permission, for instance by giving people who had just arrived in the town and were unaware of the town's trading policies the chance to buy the appropriate permit. As a result, theoretically only those who were unwilling to comply with the regulations as set out by the local shopkeepers' guild would be affected by policing activities, and were punished by a confiscation of their goods, and liable to paying a fine. Nevertheless, the policies regarding the policing of illegal street traders did leave room for misuse, and some elements may have even stimulated people to abuse their powers. ${ }^{63}$ In the Arnhem guild ordinances, for instance, the guild clerk was explicitly ordered not to work hand and glove with someone else, nor privately to arrest people for his own gain. ${ }^{6}$ Evidence from Antwerp, a city in the neighbouring Southern Netherlands, reveals that municipal officials were occasionally bribed to allow the sale of goods from out of town, and it is very likely that similar acts of fraud also occurred north of the border. ${ }^{6}$ Indeed, evidence from Zwolle

${ }^{61}$ GA, GGA, no. 1646; GDH, AAB, nos. 133-8. Calculations based on De Vries and Van der Woude, The first modern economy, pp. 610-13. For the sales licences, we do not have prices for Arnhem or The Hague; I therefore have taken the price of a sales licence in Zwolle as wage levels in Arnhem and Zwolle were similar.

62 Streng, Vrijheid, p. 98; Bot, 'Comansgilde', p. 26; Jongman, 'Kruideniersbedrijf', p. 62.

63 Compare the situation in Venice. Shaw, Justice, pp. $7 \mathrm{O}^{-} 4$.

64 GA, GGA, no. 1448; see also Streng, Vrijheid, pp. 190-2, and Welch, Shopping, p. 76, for similar evidence on Zwolle and Italy respectively.

${ }_{5}$ Ilja Van Damme, Verleiden en verkopen: Antwerpse kleinhandelaars en hun klanten in tijden van

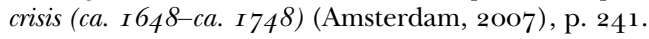


showed that clandestine sales licences with a validity of one year (instead of the stipulated three days) were occasionally sold in return for a much higher fee in order to boost the income of the official. ${ }^{66}$ Local shopkeepers may in addition have been inspired to use their powers to get rid of (legal) competitors, and the substantial rewards offered for spying on, the giving away, and arresting of suspects may have encouraged more arrests than justified. The question therefore is what happened in practice. What measures did shopkeepers' guilds and the people operating on their behalf use to stop illegal vendors? Who were the people they ultimately arrested?

\section{I I}

In the hunt for illegal salespeople, specific groups were singled out, and Jewish people in particular were victims of surveillance. The Arnhem shopkeepers' guild specifically ordered its clerk to look out for Jewish chapmen, while, as we have read before, the Zwolle guild paid extra for arresting Jewish salesmen. ${ }^{67}$ In line with these policies, the town of Zierikzee explicitly ordered that Jewish people could not hawk their wares during the town's fairs. ${ }^{68}$ As suggested by Laurence Fontaine, the singling out of Jewish traders was part of a deliberate marginalization of travelling salesmen by stationary retailers who feared their competition and can be seen throughout early modern Europe. By turning itinerant traders into anonymous strangers, even if they operated in a particular locality on a regular basis, the retail establishment aimed to increase the willingness of local customers to agree to their arrests. ${ }^{69}$ In a similar way, female hawkers were specifically targeted in municipal ordinances designed to suppress the disorderly behaviour of street vendors. In such ordinances, female vegetable sellers and the proverbial fishwives were portrayed as notorious and dangerous rioters, whose behaviour was a threat to the public order. $7^{\circ}$ Such portrayals resemble what has been earlier established for early modern London by Laura Gowing who found that women street vendors were linked by the local authorities to the spread of diseases and sexual disorder. $7^{11}$ The negative portrayals of specific groups of ambulant traders, and the active calls for their

66 Streng, Vrijheid, 65 .

67 GA, GGA, no.1448.

68 Remmerswaal, Alliantie, p. 120.

69 Fontaine, Pedlars, p. $16_{5}$.

$7^{\circ}$ Danielle van den Heuvel, 'The multiple identities of early modern Dutch fishwives', SIGNS, 37 (2012) pp. 587-94; Rudolf Dekker, 'Women in revolt: popular protest and its social basis in Holland in the seventeenth and eighteenth centuries', Theory and History, 16 (1987), pp. 337-62.

$7^{1}$ Laura Gowing, 'The freedom of the streets: women and social space, ${ }_{15}^{60-1640 ', ~ i n ~ M a r k ~}$ Jenner and Paul Griffiths, eds., Londinopolis: a social and cultural history of early modern London, I 500-I750 (Manchester, 2000), pp. 138, 140-1. 
arrest, will undoubtedly have resulted in unjustified detainments, for which we find several traces in the local archives. $7^{2}$

In addition to negatively portraying ambulant traders, the monitoring of peddlers will have further affected their public profiles. There is some discussion on whether the surveillance by guilds was very effective, as some historians claim searches were infrequent and, if carried out at all, mostly on pre-established days.73 The regulation on retailing issued by Dutch shopkeepers' guilds aimed to subject peddlers and hawkers to close and constant examination. The evidence on the arrests of traders showed that monitoring happened in streets and squares, and as several examples show, even in their lodgings or in the homes of their customers, itinerant traders were not free from monitoring. The salesman Roelof van Dordth, mentioned above, was arrested at his lodgings, and the Jewish vendor Moses Ephrahim was apprehended in the house of his client Mrs van Dartelen.74 Moreover, the fact that rewards were also offered to members of the public for assisting in apprehensions meant that the surveillance of illegal hawkers and peddlers did not depend solely on (periodical) searches by guild officials. 75 The initial wariness of retailers to sell certain products to their customers we can observe in some of the testimonies clearly stems from their worries of being uncovered by people who in fact operated on behalf of the guild. $7^{6}$ The registration of fines paid by traders after they were arrested in the cities of Arnhem and The Hague furthermore illustrates that monitoring and apprehensions took place throughout the year, as fines were taken down from January to December with only minimal clustering in the (for ambulant traders) busier summer months. 77

Being shadowed by guild clerks, local officials, or even soldiers must have had a deleterious effect on a trader's reputation. This was only exacerbated in the case of an arrest. As the arrests were generally carried out in public, they caused great embarrassment for the trader involved. For instance, when Hendrick Bruijning complained to the Arnhem magistrates about being arrested unjustly by the local guild, he stressed in particular that the 'public'

$7^{2}$ GA, GGA, nos. 1410, 1411, 1420; Menno Potjer, 'Joden in Arnhem in de 18e eeuw: frivole avances en andere problemen', Arnhem de Genoeglijkste, 22 (2002), pp. 82-91.

73 See for instance Michael Berlin, "Broken all in pieces": artisans and the regulation of workmanship in early modern London', in Geoffrey Crossick, ed., The artisan and the European town, 1500-1900 (Aldershot, 1997), p. 79; P. Wallis, 'Controlling commodities: search and reconciliation in early modern livery companies', in I. A. Gadd and P. Wallis, eds., Guilds, society, and economy in London, I450-I80o (London, 2002) p. 88; I. W. Archer, The pursuit of stability: social relations in Elizabethan London (Cambridge, 2002), pp. 126-7; I. A. Gadd and P. Wallis, 'Reaching beyond the city wall: London guilds and national regulation, 1500-1700', in Epstein and Prak, Guilds, pp. 296-301.

74 GA, GGA, nos. 1405 and 1411.

75 Streng, Vrijheid, pp. 74, 94 .

${ }^{7}$ Van Damme, Verleiden, pp. 139-40.

77 GA, GGA, no. 1646; GDH, AAB, nos. 133-8. 
confiscation of his goods caused him great damage. $7^{8}$ Indeed, in a time when personal relations were crucial to enforce trust between a trader and his customer, an arrest by guild or government officials, even if it was unjustified, could be enough to indicate that one was an unreliable trader, and to ruin ones reputation. 79

Apart from impacting on the trader's public profile and customer relations, the searches and arrests could also impact on traders in another way. Evidence shows that in their approach towards itinerant traders, guild representatives did not always behave in as controlled a way as the guild ordinances ordered them to do. ${ }^{80}$ Accounts of violence, intimidation, and destruction of property are common in petitions and court cases concerning traders. For instance, in ${ }^{1696}$ in Vlissingen, a female street seller from the neighbouring town of Middelburg complained to the guild about the 'disgraceful way' in which her goods were taken by guild representatives who, amongst others, used swear words against her. ${ }^{81}$ Also, when the aforementioned Hendrick Bruijning was apprehended, the officials of the shopkeepers' guild treated him rather violently. Bruijning, who was an Arnhem local but not a guild member, sold textiles at the annual fair and weekly market. When transporting his goods home the day after the market, the guild's wardens, bookkeeper, and clerk stopped him and accused him of having sold products from his home - an act that was strictly forbidden to non-guild members. They pushed over his cart, which he used for transporting his wares, and seized the pieces of cloth he was carrying. ${ }^{82}$ The records do not tell us whether the seizure of his goods was justified due to his reluctance to obey the guild representatives. As Bruijning claimed the accusations were false, it is very likely that he would have protested at his arrest, and would not have been willing to follow the orders of the guild's representatives. Nevertheless, although it is unknown whether his response to the guild representatives provoked an aggressive but possibly justified response, we can be sure that the pushing over of his cart, and thereby risking damage to the cart and the goods it carried, was not one of the official methods of the guild to stop black-market traders.

The case of Hendrick Bruijning highlights three dangers to the way the policing of street vendors was organized by shopkeepers' guilds in the Dutch Republic. First, it shows that when people were falsely accused, and they were therefore unwilling to co-operate with the guild representatives in their arrest, it left the guild with the right to claim the power to seize the street

$7^{8}$ GA, GGA, no. 1408. In Dutch: 'sijne opgeladene goederen alsoo Publicq op de straet te ontneemen'.

79 Compare Welch, Shopping, pp. 93-4; Shaw, Justice, 95. See also the argument advanced by Postles on the market place as a site of public punishment and its effect on honour. D. Postles, 'The market place as space in early modern England', Social History, 29 (2004), pp. $4^{1-5} 8$.

8o GA, GGA, no. 1448 .

${ }^{81}$ Gemeentearchief Vlissingen, Archief van het kramersgilde, G-44, fo. 77 .

${ }^{82}$ GA, GGA, no. 1408 . 
traders' wares, even though this was technically unjustified. Other evidence shows that when goods were illegitimately confiscated, retailers often had to wait months or years for them to be returned. ${ }^{8}$ For example, in $175^{2}$, Willemina Monnik, another Arnhem local, was unjustly targeted by the guild clerk who stopped her in the street and seized a piece of linen she was carrying. After three years, the linen still had not been returned to her, for which she turned to the town's magistrates for help. Unfortunately, there is no information on the exact size and value of Monnik's piece of linen, but the very fact that even after a three-year period she felt it was worthwhile to petition for it to be returned indicates that it must have been worth the effort. ${ }^{84}$ Naturally, having one's commercial goods confiscated for such a long period could greatly impact on one's business, which was also the case when large amounts of wares were seized such as in the case of a trader in the town of Goes who had 1 oo containers of black die confiscated by the guild. ${ }^{8}$ But even a day's delay could cause considerable problems, especially in the context of annual fairs which after all only lasted for a limited number of days. This happened to a peddler who, on his way to the neighbouring town of Nijmegen, arrived at an Arnhem inn where he was instantly arrested by the guild clerk, without having engaged in any sales activities. Although the local magistrates cleared him of the accusations by the guild clerk the day after his arrest, it meant his business suffered as his travel to the Nijmegen fair was delayed by a full day. ${ }^{86}$

Secondly, the case of Bruijning shows that to be arrested one did not actually have to be caught in the act. ${ }^{87}$ Arrests could be executed days, or even weeks, after committing the offence. In the case of Bruijning, the guild responded to a suspicion of him having sold wares from his home but targeted him at a later moment, when he was going from the market to his home. Another case, this time from the mid-seventeenth century, also shows a vendor being arrested ten days after the supposed black-market transition had taken place. ${ }^{88}$ The fact that ambulant traders did not have to be caught in the act further weakened the position of retailers who were not guild members. It made the reporting of illegal traders by guild members more susceptible to fraud, for instance for local shopkeepers trying to get rid of competitors who could report street vendors without actual proof of illegal activities.

Lastly, Bruijning's case shows that the violence used in targeting suspects was not limited to paid employees of the guild, such as the bookkeeper and the clerk, but that even the members' of the guild's government gave in to

${ }^{83}$ GA, GGA, nos. 1408,1411 , and 1426 .

${ }^{8} 4$ GA, GGA, no. 1426 .

85 Remmerswaal, Alliantie, p. 118.

${ }^{86}$ GA, GGA, no. 1417.

87 This was not the case in Zierikzee where it was stipulated in 1727 that illegal vendors had to be caught in the act to be punished. Remmerswaal, Alliantie, p. 117 .

88 GA, GGA, no. $13^{86 .}$ 
aggressive behaviour towards street traders. We find this in other cases as well, such as in Amsterdam in 1695 where the aggression against traders who were not guild members went even further. In this case, a guild clerk and a city official attempted to demolish a stall of two illegal female booksellers, only to be stopped at the last minute by the urban magistrates. ${ }^{8} 9$ In the southern town of Den Bosch in 1711 , the guild wardens and two assistants to the bailiff plundered the stalls of five Jewish retailers, the latter even encouraging soldiers to join them as the stallholders were 'only Jews'. $9^{\circ}$

The examples of what the policing of ambulant traders actually comprised shows that even though in their regulations the shopkeepers' guilds may have attempted to ensure that non-guild members would have had a fair chance to acquire the obligatory permits, and to defend themselves against the actions by guild representatives, in reality their position was rather weak. The guild rhetoric primarily singled out Jewish traders as fraudsters, and municipal ordinances were often especially directed towards hucksters, and this will undoubtedly have led to relatively greater activities against Jewish peddlers and female hawkers. Nevertheless, it has been shown that also local male hawkers could suffer substantially from the urge of shopkeepers' guilds to act against possible suspicious retail activities. This last observation leads to the question of who precisely were the victims of the policing activities by shopkeepers' guilds, and this is a question we will turn to now.

\section{V}

In the historiography of informal work, and of illegal street selling in particular, there is a notion that, despite extensive legislation against black-market retailing, very few people actually suffered from restrictions imposed on such activities, as guilds were either unable or unwilling to enforce strict control. This assumption is generally based on observations of the constant repetition of ordinances prohibiting street trade, on repeated observations of street traders who were first charged but later let off the hook, and on the limited numbers of arrests made by the authorities. $9^{1}$ Nevertheless, in assessing whether there was any suffering as a result of guild activity against illegal street trade and in identifying who precisely suffered from such activities, it is important to realize that direct evidence such as ordinances and reports of arrests reveals only part of the story. The fines that were paid to Dutch shopkeepers' guilds as a result of the arrests of black-market traders are a case in point.

When all strategies to convince people to stop trading without permission failed, the guild issued a fine. These fines were the final step in the policing

89 Salman, 'Peddling'.

$9^{\circ}$ Vos, Burgers, p. 61.

$9^{1}$ Stabel, 'Market', p. 104; Streng, Vrijheid, p. 84; Welch, Shopping, p. 93; Fontaine, Pedlars, p. 166; Buchner and Hoffmann-Rehnitz, 'Introduction', p. 28; Shaw, Justice, pp. 91-4, 103-5; Brunelle, 'Policing'. 
activities against illegal street vendors in Dutch towns, and the people fined are the most obvious victims of policing. For two shopkeepers' guilds, that of The Hague and that of Arnhem, lists of fines have survived in the guilds' financial administrations. $9^{2}$ We saw earlier that the fines imposed on black-market traders in these cities were so high that we can reasonably assume that it had serious consequences on their livelihood. Especially the higher fines issued by these guilds had the potential to put a street vendor out of business. It is furthermore likely that people contemplating selling wares in the streets of Arnhem and The Hague may have decided otherwise after learning of such considerable financial threats.

When analysing the lists of fines, two further things stand out. The first striking find is that the numbers of fines that were paid to these guilds were rather low. Between 1700 and 1798 , in The Hague 92 fines were recorded and in Arnhem between 1698 and 1796122 fines. Relative to the population, substantially fewer fines were paid in The Hague than in Arnhem, which is probably mostly down to differences in guild monopolies.93 More important in this context is, however, that on average over the period under study only one fine per year was paid to each guild. This result does not seem to match the determination of both guilds in stopping people infringing on their monopoly, which appeared from their policies and actions against street vendors as exposed earlier. On the basis of the number of fines issued by these two guilds, one could argue that only very few people were affected by policing activities; this would be in line with recent interpretations of the effectiveness of policing of illegal traders.

However, on closer analysis, the lists of fines reveal another striking finding, which shows that the fines do not expose the full impact of policing. An analysis of the profiles of the fine payers discloses that these do not match the identities of those groups that were specifically targeted in the ordinances (Jewish traders and women), and, perhaps more importantly still, they also do not correspond with the profile of the people who we have found being harassed by guild and government officials whilst selling wares on the streets (local men and women, and Jewish traders). Indeed, what appears from the analysis of the profiles of the fine payers is that those who were forced to pay a fine formed a very specific social group, and that this group was almost identical in both towns, despite differences in the size of the towns, their institutional set up, and the character of their economies.

First, although women were abundant in street vending, and in regulation against illegal street vending, women were explicitly targeted, we find that the

$9^{2}$ These records have not been previously studied and I am unaware of the existence of such extensive lists elsewhere. Shaw for Venice uses registers of criminal denunciations at the Giustizia Vecchia, which only have survived for the years 1615 and 1628 . Shaw, Justice, p. 75 .

93 The guild in The Hague only covered the sales of textiles and exotic goods whereas the Arnhem guild incorporated all retail trades. An additional reason may be that for the period ${ }^{1773-92}$ no records have survived on fine payments in The Hague. 
majority of the sellers were men. The gender division among fine payers was remarkably similar, and in both towns 80 per cent of the traders paying a fine were men; women only comprised 14 per cent in The Hague and 16 per cent in Arnhem. 94 Secondly, despite being specifically targeted, only a relatively small share of the traders forced to pay a fine were Jewish. Jewish traders account for only 20 per cent of fine payers in Arnhem and 23 per cent in The Hague. This is rather remarkable as we know that Jewish people formed a substantial part of the peddlers active in the Dutch Republic, and, as we saw earlier, that they were regularly singled out to be targeted by the guild clerk in his searches for illegal trade activities. The latter was the case in Arnhem, and also in the Zeeland town of Vlissingen. Interestingly, however, this was not an explicit policy in The Hague, but the share of Jewish peddlers among people paying a fine in The Hague was only slightly smaller than in Arnhem. In sum, regardless of the suspicion and the extent of regulation against Jewish traders, their shares among fine payers were relatively low.

A third feature that stands out when looking at the fine payers' profiles is that in both towns the majority of the people listed in the guilds' account books were strangers. The share of local people paying a fine was small, comprising only 6 per cent and 15 per cent of the vendors whose origin is stated in the fines lists in Arnhem and The Hague respectively. 95 The exact origins of the strangers show some variation between the two towns, with a greater geographical diversity amongst fine payers in The Hague than in Arnhem. Finally, in the trade specialization of the fine-paying vendors there was a large overlap as well. Interestingly, this was regardless of differences in guild monopoly between Arnhem and The Hague, with the Arnhem guild covering a much greater part of the local retail sector, and in the character of the local retail sector, with The Hague firmly preceding Arnhem in the advance of retail and consumer transformations..$^{6}$ In both towns, the majority of the traders who were forced to pay a fine dealt in accessories and textiles when arrested. Around 40 per cent of all traders paying a fine engaged in the selling of fashion accessories and of small items of clothing. Textiles, such as woollens, cottons, but especially linens, were also sold by a very large share $\left(32\right.$ per cent in The Hague and $4^{\mathrm{O}}$ per cent in Arnhem) of the illegal traders who paid a fine. This finding is consistent with

94 For the remaining 6 per cent in The Hague and 4 per cent in Arnhem, it was impossible to establish their gender based on the entries in the guilds' account books.

95 There is one woman in the lists of people being fined who was from Arnhem, and is described as being a burgher (citizen). It is therefore possible that she is a local shopkeeper who was fined for not obeying to the guild's regulation. Since we do not know her name, it is impossible to find out if she was indeed a guild member. However, the simple fact that her name is not taken down may very well indicate that she was a local woman who was indeed a citizen, but was unknown to the guild's clerk.

$9^{6}$ Th. Wijsenbeek, 'Winkelen in Den Haag, $1575^{-1} 795$. Ontwikkeling van de detailhandel' (unpublished paper); Van den Heuvel, Women, pp. 177-215; Van den Heuvel and Ogilvie, 'Retail development', pp. $69-87$. 
what we know about the products sold by the foreign peddlers travelling through the Northern Netherlands. 97

The finding that precisely male long-distance peddlers were predominant amongst those who were formally punished for illegal street vending illustrates that the fine payers were only a fraction of the sellers affected by policing activities of guilds..$^{8}$ As we saw earlier, more indirect and less quantifiable materials on policing activities reveal that a much wider group of traders was affected, including Jews, women, and locals. Interestingly, these materials also help us understand why the few people who were fined formed such a homogeneous group in different urban contexts.

\section{$\mathrm{V}$}

What appears very clearly from evidence surfacing from petitions and court cases is that those groups of street vendors absent from the fine payers' lists were not left untouched by the guilds, but were able to negotiate some room for manoeuvre. As mentioned earlier, in the Dutch Republic, retail guilds were the prime instigators of the prosecution of black-market traders. As a result, the local magistrates provided neutral ground to which both the guild and the prosecuted traders could turn to when they felt treated unjustly by the other party. In Arnhem, victims of policing regularly appealed before the local magistrates against the prosecution by the shopkeepers' guild. After hearing a case, the magistrates consulted the guild wardens who were generally ordered to report back on the issue within a few days.99 Very often, the magistrates issued for witnesses to be questioned on the case, and their testimonies repeatedly proved decisive. The linen seller Helena van Almelo, for instance, was acquitted in 1720 as the witnesses told the Arnhem authorities they did not have any proof of her selling illegally. ${ }^{100}$ The effort that went into settling the appeals from prosecuted traders shows that the magistrates took their cries for help seriously: the extensive questioning of witnesses took time, and the decisions were very often favourable to the prosecuted hawkers and peddlers. In September 1717 , the Arnhem magistrates questioned no less than six people on the suspected illegal sales activities of the foreign tea seller Ms Buijs. Six individuals were questioned on the case, including Ms Buijs's landlord and his wife. ${ }^{101}$ This case not only illustrates the persistence of the Arnhem guild to stop individuals from infringing on their privileges, as it revolves

97 Schrover, Kolonie, Oberpenning, Migration.

$9^{8}$ Compare the prosecution and punishments at the Assizes and Quarter Sessions in early modern England. J. M. Beattie, Crime and the courts in England I660-I80o (Oxford, 1986), pp. 400-49; C. Herrup, The common peace: participation and the criminal law in seventeenthcentury England (Cambridge, 1987), p. 198.

99 GA, GGA, nos. $1397,1408$.

${ }^{100}$ GA, GGA, nos. $1410,1457$.

${ }^{101}$ GA, GGA, no. 1453 . 
around sales activities which had taken place six months before the actual questioning of witnesses, but it also shows the commitment of the local government to come to a justifiable conclusion.

The people who appealed to urban magistrates after having been arrested by shopkeepers' guilds were of different gender, origin, and religion: we encounter men and women, locals and strangers, and Christians and Jews. Despite this variety, we saw that strangers above all ended up paying a fine. The question is why they had less bargaining power than the other groups that were charged. In establishing why this is the case, it is important to acknowledge the role of both the urban magistrates and the local community. From petitions and court records, it appears that magistrates were willing to repeal guild-imposed sentences when street vendors engaged in small-scale activities that allowed them to earn just enough money to maintain a living, but were not a significant threat to the local retail sector. ${ }^{102}$ The risk that street vendors would fall into poverty and be a burden to the local poor relief system seems to have exercised the minds of the municipal authorities most, and explains why locals were less often fined than strangers. Whilst strangers generally did not have access to local poor relief systems, local traders did. It is, moreover, very well possible that magistrates were more susceptible to claims on the threat of poverty by women than by men, potentially explaining the gender gap amongst fine payers.

As was pointed out above, besides urban magistrates, the local community also had a large part to play in whether the appeals of illegal traders were successful. It is clear that local consumers benefited from the services of street vendors. Like Buijs, many street vendors sold new and exotic products, often at lower prices than shopkeepers as they had lower business costs. They also offered products on the doorstep, enabling people to buy from home, a great convenience to those tied to their home, such as young mothers, or domestic servants with a lot of work on their hands. ${ }^{103}$ The Arnhem evidence shows that women were regular customers, among them domestic servants buying from their patrons' homes. ${ }^{104}$ In addition, local shopkeepers benefited from the supply of goods via networks of ambulant traders, and innkeepers, who often acted as hosts for itinerant traders, will have welcomed peddlers as the number of clients will have increased as a result of extra activity in their inns. ${ }^{105} \mathrm{~A}$ good example of how such services were appreciated by local businesspeople is the case of the Arnhem coffeehouse holder Van Leeuwen. He

102 Salman, 'Kramers', p. 81; Streng, Vrijheid, pp. 75, 96; Brunelle, 'Policing', pp. 20-1, 27.

103 GA, GGA, nos. 1410, 141 1, 1453; GA, Oud-Rechterlijk Archief, no. 169, 2 Jan. 1668; see also L. A. Jones, 'Gender, race, and itinerant commerce in the rural New South', Journal of Southern History, 66 (2000), pp. 297-320.

104 GA, GGA, nos. 1411, 1419, 1420, 1453; Menno Potjer, De Velperweg in kaart gebracht. Eigenaren en eigenaardigheden (Westervoort, 2008), p. 124.

105 Remmerswaal, Alliantie, pp. 116-17; Braudel, Wheels, p. 8o; Berger, Luxuries, pp. 174-5; Montenach, 'Formal', pp. 98-9; Salman,'Peddling', p. 9; Shaw, Justice, p. 81. 
actually paid the guild to regain the merchandise of Jewish peddler Jacob Levi, one of his regular customers, after it was confiscated by the clerk. ${ }^{106}$

Although the benefits of ambulant trade play an important role in explaining why some illegal traders were tolerated, they do not provide a full explanation of why others were formally punished. In the services they offered, there were no substantial differences between those forced to pay a fine and those whose arrests were eventually repealed by the city magistrates. Moreover, among those appealing successfully against guild sanctions were several strangers. What probably made the difference in their case, however, is that those strangers who were successful in their appeal were regular visitors to the towns they operated in, and thus part of the local retail community - albeit that the local guild saw that differently. ${ }^{107}$ Crucial in determining the outcome of an arrest by guild officials therefore was whether, and to what extent, one was considered as part of the local community. As has been argued with regards to poor relief applicants and suspects of crime, for people who were not officially part of the civic community, a sense of place and belonging was critical in securing a beneficial outcome in processes of local governance. ${ }^{108}$ For street vendors, therefore, to be regarded as an 'insider' made all the difference, not so much in the treatment by the guild, but rather in the perception of the urban magistrates, and, especially, local consumers who, as assistants in arrests and as witnesses in cases of appeal, played a decisive role in determining who could transfer from the black to the grey market.

Finally, we must consider another factor in the process of being arrested and the outcome such an arrest eventually took. As we read above, the regulatory framework allowed for interpersonal bullying. Shopkeepers wanting to get rid of competitors, and guild clerks and other officials hoping to boost their income were given leeway to harass itinerant traders through the way in which the governance of retail trade was organized. ${ }^{109}$ Indeed, this is precisely what the earlier introduced Willemina Monnik claimed the guild clerk had done to her. According to Willemina, as she told the Arnhem magistrates, the guild clerk was simply 'pestering' (vexeren) her, while he had no right doing so, as she was not selling the wares she carried. ${ }^{10}$ We have seen that such bullying was not always condoned by the civic leaders. In the case of Willemina, the guild was ordered to return her goods as the claims about supposed sales activities were false. An even more extreme example shows that in the same town in

106 GA, GGA, no. 1420.

${ }^{107}$ Research by Oberpenning shows that some peddlers paid regular visits to Dutch towns over exceptionally long time spans of up to twenty-six years. Oberpenning, Migration, p. 301.

${ }^{108}$ Herrup, Common peace, pp. 197-200; S. Hindle, 'A sense of place? Becoming and belonging in the rural parish, $155^{\mathrm{O}-16} 5^{\circ}$ ', in A. Shepard and P. Withington, eds., Communities in early modern England: networks, place, rethoric (Manchester, 200o), pp. 96-1 14, P. Withington, The politics of Commonwealth: citizens and freemen in early modern England (Cambridge, 2005) pp. 183-9.

109 Streng, Vrijheid, p. 97.

110 GA, GGA, no. 1426 . 
1738 a man was ordered to pay no less than 125 guilders in compensation for illegally confiscating goods of the wife of a well-known Jewish peddler. ${ }^{111}$ Nevertheless, although municipal authorities in the Dutch Republic were in many cases willing to mitigate between accuser and the accused, the system did leave plenty of room for misuse, and left ambulant traders vulnerable to attacks from guilds and their members. Whether and to what extent street vendors were pursued and arrested may thus have been down to chance, but the risk of being apprehended was a continuous threat. Apprehension could theoretically take place at any moment, instigated not just by guild personnel but by anyone, including local shopkeepers, and civic officials, and also random customers and passers-by. As is shown in studies on modern developing countries, the sheer possibility of being targeted weakens the position of street vendors, who as a result are limited in their business activities (when, where, what, how much, and to whom they sell), even in the case of those who are lucky enough to escape actual prosecution; there is no reason to assume that street vendors in early modern Europe were affected any differently by the threat of prosecution. ${ }^{112}$

\section{I}

Street traders formed an important part of the early modern distribution system, in both urban and rural areas. However, many ambulant traders operating in Europe's towns and cities lacked official permission for their activities, despite extensive regulation of urban retailing. Understanding why this was the case and how this impacted on the people involved is a complicated task. This article aimed to shed light on the implications of regulatory regimes and mechanisms of enforcement in the context of ambulant trading, based on an in-depth study of policing activities against street vendors in eighteenthcentury Dutch towns.

In Dutch urban centres, as elsewhere in Europe, ambulant trading was subject to strict regulations. Although most ambulant traders were free to purchase a membership of a retail guild and therewith obtain legality, not every trader was able to afford the costs involved. Those unable to fund guild membership were left with limited opportunities to sell their wares. In most towns, ambulant trade was only allowed for restricted periods of time, for instance during fairs and markets, or when in possession of a temporary sales licence. The enforcement of retail regulations was in the hands of the local guilds, which generally had extensive policies on the policing of peddlers. What appears from these

\footnotetext{
${ }^{111}$ It is unknown whether this amount represents the value of the confiscated goods, or also covers compensation for possible maltreatment. Potjer, 'Joden'.

112 M. Cohen, Women street vendors: the road to recognition (New York, NY, 2000) pp. 8-9; Horn, Cushion, pp. 16, 22-3, 26; U. Kothari, 'Global peddlers and local networks: migrant cosmopolitanisms', Environment and Planning D: Society and Space, 26 (2008), pp. 5o8-9. See also http:// wiego.org/informal-economy/occupational-groups/street-vendors.
} 
policies is that the authorities had difficulties containing the activities of illegal street vendors. While the surveillance and prosecution of illegal street vendors was an important part of the guilds' activities, the fact that several guilds had to resort to paying premiums, and had to involve others in the arrests, illustrates that their powers regularly failed them. Additionally, we found that the number of people who were arrested and subsequently fined for black-market trading was relatively low. This suggests that, as has indeed been claimed for other areas in Europe, the policing of illegal street vending in early modern Dutch towns claimed only very few victims.

However, by investigating more closely what happened to street vendors when policed and subsequently arrested, this article exposed that the actual effects of policing for the individuals involved could be much larger than those that surface at first glance. The first finding is that whilst the rules set out by guilds regarding the policing of street vendors in principle guaranteed a fair treatment of those who were engaging in retailing without guild permission, in practice this was not always the case. Many of the regulations left room for misuse, and as a result street vendors ran the risk of being arrested without a proper cause, or even worse, verbally or physically assaulted by guild officials. Secondly, and related to this, we found that street vendors who were not being forced to pay a fine were not left untouched. Street vendors, whether or not they were ultimately arrested or fined, were subject to surveillance, public apprehensions, and confiscation of goods, which could greatly affect their business operations and their customer relations. Thirdly, it appeared that different groups of street vendors were affected differently by policing activities. While guild and government policies specifically targeted Jewish traders and female hawkers, and while these groups were also regularly apprehended by the guilds, they only formed a small share of those traders who eventually paid a fine to the guild. On the contrary, male long-distance peddlers were the most likely to receive such formal punishment. These findings raise the crucial question of how discretionary the prosecution and sentencing of itinerant traders was. This article showed that magistrates on many occasions were willing to tolerate the activities of peddlers, but that the character of guild regulation allowed others of less authority to harass those made vulnerable by the law. Overall, those street sellers who were most firmly grounded in the local community were most likely to have a formal punishment by the guild repealed through intervention of the local magistrates. This resembles the discretion exercised in criminal cases and the administration of poor relief. Such discretion, of course, did not take away that at the time of the appeal vendors had already suffered substantial damages to both their trade and reputation as a result of harassment by guild officials and their accomplices.

The findings presented here have important implications for our understanding of the interplay between formal and informal segments of the early modern urban economy, and, indeed, of early modern society more widely. The observations that rules were bent by guild officials, and punishments repealed for 
some but not for others, expose the complex dynamics of the policing process, in which, as other scholars have stressed before, flexibility and negotiation were key elements. Although hitherto such flexibility has been largely regarded positively, this study has revealed a darker side to 'bending the rules'. While this article has shown that Dutch retail guilds were flexible in applying sentences for black-market retailing and offered informal traders a route to legality through the possibility to acquire permits and guild memberships, it also illustrated the other side of the coin. By applying their own rules flexibly, guild officials could charge many more people than they were officially entitled to; at the same time, it appeared that the power to negotiate some room for manoeuvre mostly applied to specific groups of illegal traders. It is important, therefore, that when assessing the impact of policing activities we carefully examine in what way rules were bent, and who precisely benefited from such flexibility.

The observation that some groups of illegal traders were affected to a greater extent than others brings me to a further important consideration: the large role played by the local community, and especially ordinary consumers, in determining the room for negotiation and to which individuals it applied. While this group is often overlooked in discussions on struggles between formal and informal traders, it appears that they were very important in shaping which segments of ambulant trade constituted the informal economy. The illegally operating traders benefiting from discretion (locals, women, and frequent visitors to the towns) seemed to be able to access an informal sense of citizenship, beyond the formally defined civic community. ${ }^{13}$ The readiness of local consumers to turn a blind eye to unregulated activities will partly have derived from a sense of neighbourliness and community, but will, of course, also have been connected to their own economic needs. As such, it indicates that policing activities could not only affect retailers, but also consumers, and begs further questions on how the character of the local economy influenced the role of the local community in policing, and how the dependence of street vendors on their customers affected their businesses. Moreover, the fact that we observe this dynamic within a specific regulatory framework, in which guilds were the main actors in policing and the urban government and local inhabitants provided a counterbalance, opens up stimulating avenues for further, and indeed indispensable, research on how local power relations shaped the informal economy.

113 Compare Withington, Politics. 